\title{
D-glyceric aciduria
}

\author{
NÁDIA W. DIMER ${ }^{1}$, PATRÍCIA F. SCHUCK ${ }^{2}$, EMILIO L. STRECK ${ }^{1}$ and GUSTAVO C. FERREIRA ${ }^{3}$ \\ ${ }^{1}$ Laboratório de Bioenergética, Unidade Acadêmica de Ciências da Saúde, \\ Universidade do Extremo Sul Catarinense, Av. Universitária, 1105, Bloco S, Sala 6, 88806-000 Criciúma, SC, Brasil \\ ${ }^{2}$ Laboratório de Erros Inatos do Metabolismo, Unidade Acadêmica de Ciências da Saúde, \\ Universidade do Extremo Sul Catarinense, Av. Universitária, 1105, Bloco S, Sala 6, 88806-000 Criciúma, SC, Brasil \\ ${ }^{3}$ Laboratório de Bioenergética, Instituto de Bioquímica Médica Leopoldo de Meis, Universidade Federal do Rio de Janeiro, \\ Av. Carlos Chagas Filho, 373, Cidade Universitária, Ilha do Fundão, 21941-902 Rio de Janeiro, RJ, Brasil
}

Manuscript received on January 12, 2015; accepted for publication on March 27, 2015

\begin{abstract}
Inherited metabolic diseases are a heterogeneous group of diseases caused by a punctual defect in cell metabolism, resulting in the accumulation of toxic intermediate metabolites or in the lack of important biomolecules for adequate cell functioning. D-glyceric aciduria is an inherited disease caused by a deficiency of glycerate 2-kinase activity, whose pathophysiological mechanisms remain unknown. The main clinical and neurological symptoms seen in affected patients include progressive encephalopathy, hypotonia, psychomotor and mental retardation, microcephaly, seizures, speech delay, metabolic acidosis, and even death. In this review we shall discuss these clinical and biochemical findings, as well as diagnosis and treatment of affected patients in order to raise awareness about this condition.
\end{abstract}

Key words: D-glycerate, D-glyceric aciduria, glycerate kinase, glyceric acid, organic acidurias.

\section{INTRODUCTION}

Inborn errors of metabolism are biochemical hereditary diseases caused by a deficiency of selected enzymes, resulting in a blockage of a metabolic pathway (Saudubray and Sedel 2011). This interruption leads to the accumulation of the initial substrate, to the lack of the enzymatic product and/or misuse of the alternative metabolic pathway (Araújo 2004). If untreated, these metabolic disorders can lead to a number of clinical and developmental consequences, ranging from mild complications to serious mental disability and death

Correspondence to: Gustavo Costa Ferreira

E-mail: gustavo.ferreira@bioqmed.ufrj.br /

gustavo.ferreira@pq.cnpq.br
(Camp et al. 2012). Organic acidurias are inherited diseases of the catabolic pathway of carbohydrates, amino acids and lipids, presenting accumulation of one or more organic acids in tissues, urine, blood, and other body fluids of affected individuals (Scriver et al. 2001, Vargas and Wajner 2001).

Glyceric acid (2,3-dihydroxypropionic acid) is a carboxylic acid with small molecular weight and being very hard to detect during routine organic acid analysis in urine of healthy individuals (Rashed et al. 2002). This compound is found in humans in two different configurations, D- and L-glycerate (Brandt et al. 1974, 1976). Increased excretion of glyceric acid can be observed in two distinct and rare inherited metabolic diseases, D-glyceric and 
L-glyceric acidurias (the latter being also known as primary hyperoxaluria type II) (Rashed et al. 2002). The clinical phenotype of L-glyceric aciduria predominantly involves renal alterations, including recurrent nephrolithiasis, while D-glyceric aciduria mainly affects the central nervous system (Bonham et al. 1990). In this review we shall discuss the clinical and biochemical findings, diagnosis and treatment of patients affected by D-glyceric aciduria in order to raise awareness about this condition.

\section{BIOCHEMICAL FINDINGS}

D-Glyceric aciduria (OMIM 220120) is an autosomal recessive disease of the catabolism pathway of the amino acid serine and, to a lesser extent, of fructose metabolism (Rashed et al. 2002, Sass et al. 2010). The disease is caused by a deficiency of glycerate 2-kinase (EC 2.7.1.165) activity (Guo et al. 2006) and its prevalence is unknown.
In normal terms, fructose is phosphorylated by fructokinase to fructose 1-phosphate, which is converted to D-glyceraldehyde by aldolase B (Leuthardt and Testa 1951, Hers and Kusaka 1953, Leuthardt and Wolf 1954, Adelman et al. 1967) (Fig. 1). The conversion of D-glyceraldehyde to D-glyceric acid is catalyzed by aldehyde dehydrogenase (Lamprecht and Heinz 1958, Holldorf et al. 1959), and subsequently phosphorylated by liver D-glycerate 2-kinase to 2-phosphoglyceric acid, an intermediate of glycolytic pathway (Lamprecht et al. 1962). This pathway might be the major source of D-glyceric acid (Rauschenbach and Lamprecht 1964). However, under normal circumstances, most of the glyceraldehyde is phosphorylated to D-glyceraldehyde 3-phosphate by triokinase due to its high activity in human liver (Heinz et al. 1968, Van den Berghe 1978).

D-Glyceric acid is also an intermediate in the gluconeogenic pathway of the amino acid serine, which can be converted by transamination

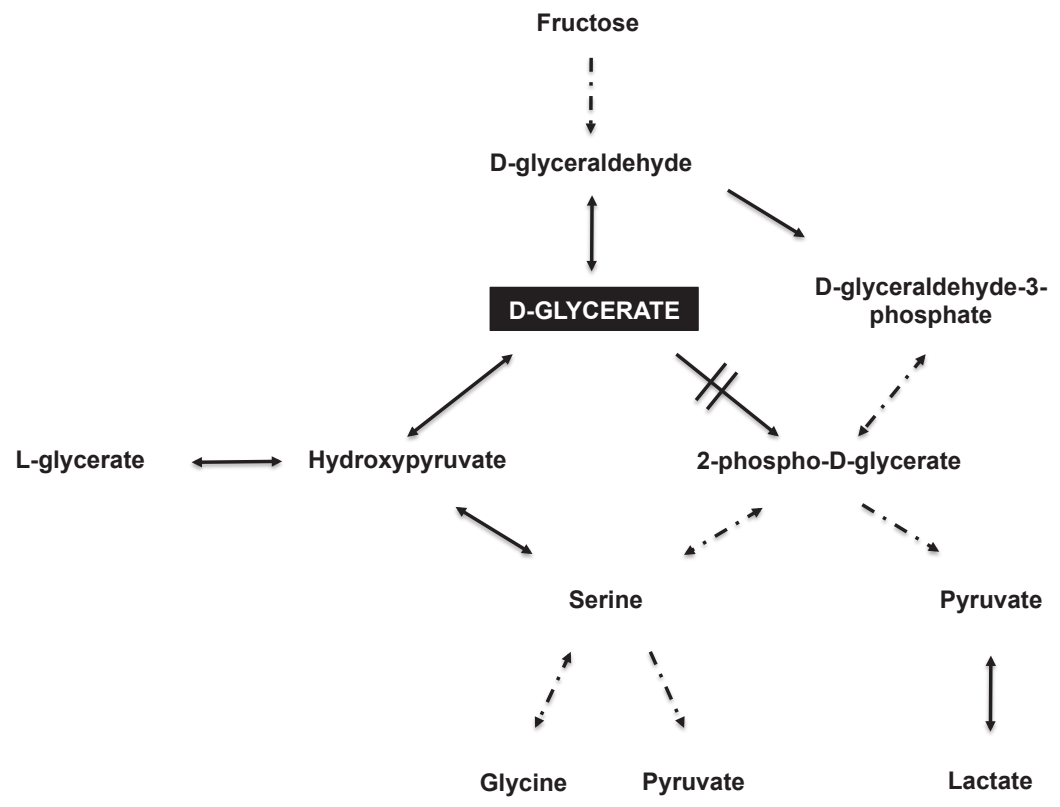

Figure 1 - Metabolic pathway involved in D-glyceric aciduria. Double-crossed arrow represents the reaction catalyzed by D-glycerate 2-kinase, which is the impaired step in the disease. Dashed lines represent multiple steps. Double-arrowed lines represent reversible steps. 
to hydroxypyruvate, the latter being reduced to D-glycerate by D-glycerate dehydrogenase (EC 1.1.1.29) (Kolvraa et al. 1976). The deficiency of D-glycerate dehydrogenase results in the accumulation of L-glycerate (Williams and Smith 1983, Mistry et al. 1988), which is produced from hydroxypyruvate by lactate dehydrogenase enzyme (Dawkins and Dickens 1965).

D-Glyceric aciduria was first reported in 1974 in a 2 year-old boy with hypotonia and severe psychomotor retardation (Brandt et al. 1974). Since then, only a few cases of children with D-glyceric aciduria have been described in the literature (Sass et al. 2010).

Patients affected by D-glyceric aciduria show increased levels of D-glyceric acid in urine and serum (Wadman et al. 1976, Fontaine et al. 1989, Schaftingen 1989, Bonham et al. 1990), as well as hyperglycinemia (Brandt et al. 1974, Sass et al. 2010). In a patient affected by D-glyceric aciduria, there was a significant elevation of hydroxyacids, free and total short-chain fatty acids, and elevated amounts of butyric and hexanoic acids together with butyrylglycine, hexanoylglycine, and suberic acid (Kolvraa et al. 1980). Based on the increased excretion of these compounds, it may be hypothesized that the diminished glycine cleavage activity is, at least in part, due to inhibition by 2-methylbutyryl-CoA and isobutyryl-CoA (compounds known to inhibit the glycine cleavage system). On the other hand, it cannot be ruled out that D-glyceric acid itself has an inhibitory effect on this system.

A marked increase of the excretion rate of D-glycerate in response to oral fructose overload in children with suspicion of D-glyceric aciduria was demonstrated (Fontaine et al. 1989, Bonham et al. 1990). The same pattern was observed after a dietary loading with L-serine (Wadman et al. 1976). On the other hand, Wadman et al. (1976) did not observe a worsening of metabolic acidosis or changes in urine acidity after an overload of fructose in a patient with D-glyceric aciduria.

\section{MOLECULAR STUDIES}

Human genes for glycerate kinase, glycerate 1 -kinase and glycerate 2-kinase were first isolated by Guo et al. (2006) and associated to D-glyceric aciduria. Further, genomic DNA was extracted from fibroblasts or peripheral blood of three patients diagnosed with D-glycerate kinase deficiency. Homozygous mutations in exon 5 of the gene encoding D-glycerate kinase were identified, including c.1448de1T (p.Phe483SerfsX2), c.1478T4G (p.Phe493Cys), and c.1558delC (p.Leu520CysfsX108) (Sass et al. 2010).

\section{CLINICAL MANIFESTATIONS}

The complete determination of the clinical features in D-glyceric aciduria is a complicated task due to its etiological and clinical heterogeneity and the small number of cases reported in the literature (Insuga et al. 2010). Patients affected by D-glyceric aciduria present progressive encephalopathy, hypotonia, psychomotor and mental retardation, microcephaly, seizures, speech delay, metabolic acidosis, and even death (Brandt et al. 1974, Grandgeorge et al. 1980, Duran et al. 1987, Insuga et al. 2010) (Wadman et al. 1976, Fontaine et al. 1989, Rashed et al. 2002). Furthermore, two patients had traces of autistic behaviors (Duran et al. 1987, Topcu et al. 2002). Some patients may remain asymptomatic with only mild neurological dysfunction (Bonham et al. 1990). In this scenario, two children found to excrete large amounts of D-glycerate were healthy and developmentally normal at 7 and 9 years of age (Bonham et al. 1990).

\section{METHODS OF DIAGNOSIS}

The diagnosis of D-glyceric aciduria may be indicated by the identification of increased urinary concentrations of glyceric acid by gas chromatography (GC) or preferably by GC coupled to mass spectrometry (GC/MS) (Sweetmann 1990). Since the extraction efficiency for glyceric acid is as low as $6 \%$ with this method, an alternative 
extraction procedure may be used by extracting aqueous phase 5 times with ethylacetate, rendering a recovery of $25 \%$ of this organic acid (Wadman et al. 1971). However, further tests are necessary in order to determine the optical configuration of the glyceric acid, in order to differentiate D-glyceric aciduria from primary hyperoxaluria type II (Kolvraa et al. 1976). There is an alternative method based on liquid chromatography coupled to tandem mass spectrometry (LC-MS/MS) for the enantiomers separation and detection of the glyceric acid stereoisomers. The method allows the detection of normal levels of D- and L-glyceric acid in urine, and it was useful for the confirmation of three cases of D-glyceric aciduria and for differentiating this disease from primary hyperoxaluria type II (Rashed et al. 2002). D-glyceric acid can also be identified in urine of patients by DEAE-Sephadex (Chalmers and Watts 1972).

\section{TREATMENT}

A palliative administration of bicarbonate was proposed for the treatment of D-glyceric aciduria, in order to compensate for the metabolic acidosis observed in the affected patients (Wadman et al. 1976). Additionally, a fructose-restricted diet was shown to provide a clinical improvement in a patient with D-glyceric aciduria, even though the authors implied that it was judged by subjective criteria (Duran et al. 1987). It should be highlighted that although this disease cannot currently be treated as effectively and easily as more common inherited diseases (PKU, for example), the increase in the number of detected cases of the disease may help identify new therapeutic protocols to prevent or alleviate symptoms, improving the quality of life of the affected patients and resulting in a better outcome.

\section{CONCLUSIONS}

D-glyceric aciduria is a disease whose pathophysiological mechanisms remain unknown. More studies are needed in order to elucidate the pathophysi- ology of brain damage found in patients affected by D-glyceric aciduria in an attempt to better characterize this disease and develop therapeutic strategies to improve quality of life of patients affected by this condition.

\section{ACKNOWLEDGMENTS}

The authors are supported with personal grants from the Conselho Nacional de Desenvolvimento Científico e Tecnológico (CNPq).

\section{RESUMO}

Doenças hereditárias metabólicas são um grupo heterogêneo de doenças causadas por um defeito pontual no metabolismo celular, resultando no acúmulo de metabólitos intermediários tóxicos ou na falta de biomoléculas importantes para o funcionamento celular adequado.Aacidúria D-glicérica é uma doença hereditária causada por uma deficiência na atividade da enzima glicerato 2-cinase, cujos mecanismos fisiopatológicos permanecem desconhecidos. Os principais sintomas clínicos e neurológicos observados nos pacientes afetados incluem encefalopatia progressiva, hipotonia, atraso mental e psicomotor, microcefalia, convulsões, atraso na fala, acidose metabólica e, inclusive, morte. Neste artigo de revisão discutiremos estes achados clínicos e bioquímicos, bem como o diagnóstico e tratamento de pacientes afetados, para ressaltar a importância de aumentar a conscientização sobre esta doença.

Palavras-chave: D-glicerato, acidúria D-glicérica, glicerato cinase. ácido glicérico, acidurias orgânicas.

\section{REFERENCES}

Adelman RC, Ballard FJ And Weinhouse S. 1967. Purification and properties of rat liver fructokinase. J Biol Chem 242: 3360-3365.

ARAÚJO APQC. 2004. Doenças metabólicas com manifestações psiquiátricas. Rev Psiq Clin 31: 285-289.

BONHAM JR, STEPHENSON TJ, CARPENTER KH, RATTENBURY JM, Cromby CH, Pollitt RJ AND Hull D. 1990. D(+)Glyceric Aciduria: Etiology and Clinical Consequences. Pediatr Res 28: 38-41. 
BRANDT NJ, BRANDT S, RASMUSSEN K AND SCHNOHEYDER F. 1974. Hyperglycericacidaemia with hyperglycinaemia: a new inborn error of metabolism. Br Med J 4: 344.

Brandt NJ, Rasmussen K, Brandt S, KolvraA S And SCHONHYDER F. 1976. D-glyceric-acidaemia and nonketotic hyperglycinaemia. Clinical and laboratory findings in a new syndrome. Acta Paediatr Scand 65: 17-22.

CAMP KM, LLOYD-PURYEAR MA AND Huntington KL. 2012. Nutritional treatment for inborn errors of metabolism: Indications, regulations, and availability of medical foods and dietary supplements using phenylketonuria as an example. Mol Genet Metab 107: 1-18.

Chalmers RA AND WATTS RWE. 1972. The quantitative excretion and gas-liquid chromatographic determination of organic acid in urine. Analyst 97: 958-967.

DAWKINS PD AND DiCKENS F. 1965. The oxidation of D- and L-glycerate by rat liver. Biochem J 94: 353-367.

DURAN M, BEEMER FA AND BRUINVIS L. 1987. D-Glyceric Acidemia: An Inborn Error Associated with Fructose Metabolism. Pediatr Res 21: 502-506.

Fontaine M, Porchet N, Largilliere C, Marrakchl S AND Lhermltte M. 1989. Biochemical Contribution to Diagnosis and Study of a New Case of D-glyceric Acidemia/Aciduria. Clin Chem 35: 2148-2151.

Grandgeorge D, FAVIER A, Bost M, Frappat P, Bon-Jet C AND GARNEL S. 1980. L'acidemie D-glycerique: a propos d'une nouvelle observation anatomo-clinique. Arch Fr Pediatr 37: 577-584.

Guo J, Hexige J And Chen L. 2006. Isolation and characterization of the human D-glyceric academia related glycerate kinase gene GLYCTK1 and its alternatively splicing variant GLYCTK2. DNA Seq 17: 1-7.

HEINZ F, LAMPRECHT W AND KiRSCH J. 1968. Enzymes of fructose metabolism in human liver. J Clin Invest 47: 1826-1832.

Hers HG AND KUSAKA T. 1953. Le metabolism du fructosei-phosphate dans le foie. Biochim Biophys Acta 11: 427.

Holldorf A, Holldorf C, Schneider G AND Holzer H. 1959. Aldehyd Dehydrogenase aus Leber, ein Enzym des Fructosestoffwechsels. Z Naturforsch 14: 229.

Insuga VMS, ReQuena PT, Bermejo AM, MERINo M, arcas J, De la Puente A, Viana H, Murias S and GARCía MJ. 2010. Aciduria D-glicérica. A propósito de un caso y revisión de la bibliografia. Acta Pediatr Esp 68: 79-83.

KolvraA S, GREGERSEN N AND BRANDT NJ. 1980. Excretion of short-chain $\mathrm{N}$-acylglycines in the urine of a patient with D-glyceric acidemia. Clin Chim Acta 106: 215-221.

KolvraA S, RASMUSSEN K AND BRANDT NJ. 1976. D-Glyceric Acidemia: Biochemical Studies of a New Syndrome. Pediat Res 10: 825-530.

LAMPRECHT W AND HEINZ F. 1958. Isolierung von Glycerinaldehyd-Dehydrogenase aus Rattenleber. Zur
Biochemie des Fructosestoffwechsels. Z Naturforsch 13: 464-465.

LAMPRECHT W, Heinz F AND DiAmantstein T. 1962. Phosphorylierung von D-Glycerinsaure zu 2-PhosphoD-glycerinsaure mit Glyceratkinase der Leber II. Identifizierung des Reaktionsproduktes durch Papierchromatographie. Z Physiol Chem 328: 204-206.

LeUthaRdT F AND Testa E. 1951. Die Phosphorylierung des Fructose in der Leber. Helv Chim Acta 34: 931-938.

LEUTHARDT F AND WOLF HP. 1954. Uber die Spezifitit der Aldolasen. Helv Chim Acta 37: 1734-1747.

Mistry J, DANPURE CJ AND CHALMERS RA. 1988. Hepatic D-glycerate dehydrogenase and glyoxylate reductase deficiency in primary hyperoxaluria type 2 . Biochem Soc Trans 16: 626-627.

RASHED MS, ABOUL-ENEIM HY, ALAMOUDI M, JAKOB M, ALAhaideb LY, AbBad A, Shabib S AND AL-Jishi E. 2002. Chiral liquid chromatography tandem mass spectrometry in the determination of the configuration of glyceric acid in urine of patients with D-glyceric and L-glyceric acidurias. Biomed Chromatogr 16: 191-198.

RAUSCHENBACH P AND LAMPRECHT W. 1964. Einbau von ${ }^{14} \mathrm{C}$-markierter Glucose und Fructose in Leberglykogen. Zum Fructosestoffwechsel in der Leber. Z Physiol Chem 339: 277-292.

SASS JO, FISCHER K AND WANG R. 2010. D-glyceric aciduria is caused by genetic deficiency of D-glycerate kinase (GLYCTK). Hum Mutat 31: 1280-1285.

SAudubray JM AND Sedel F. 2011. Classification et circonstance de découverte des maladies héréditaires du métabolisme. In: Chabrol B and De Lonlay P (Eds), Progrés en pédiatrie - maladies métaboliques héréditaires. Paris: Wolters Kluwer France, Paris, France, p. 1-10.

SCHAFTINGEN VE. 1989. D-glycerate kinase deficiency as a cause of D-glyceric aciduria. FASEB 243: 127-131.

SCRIVER CR, BEAUdET A, SKY WS AND VALle D. 2001. The metabolic and molecular bases of inherited disease. $8^{\text {th }}$ ed., New York: McGraw-Hill, New York, USA.

SWEETMANN L. 1990. Organic acid analysis. In: Hommes FA (Ed), Techniques in diagnostic human biochemical genetics: a laboratory mannual. New York: Wiley-Liss, New York, USA, p. 143-176.

Topcu M, SAATCi I, Haliloglu G, Kesimer M AND COSKun T. 2002. D-glyceric aciduria in a six-month-old boy presenting with West syndrome and autistic behaviour. Neuropediatrics 33: 47-50.

VAN DEN BERGHE G. 1978. Metabolic effects of fructose in the liver. Curr Top Cell Regul 13: 97-135.

VARGAS CR AND WAJNER M. 2001. Acidúrias orgânicas: diagnóstico e tratamento. J Pediatr 45: 77-82.

WADMAN SK ET AL. 1976. D-glyceric acidemia in a patient with chronic metabolic acidosis. Clin Chim Acta 71: 477-484.

WADMAN SK, VAN DER HeIDEN C, KetTING D AND VAN SPRANG J. 1971. Abnormal tyrosine and phenylalanine 
metabolism in patients with tyrosyluria and phenylketonuria; gas-liquid chromatographic analysis of urinary metabolites. Clin Chim Acta 34: 277-287.
WILliAMs HE AND SMITH LH. 1983. Primary hyperoxaluria. In: Stanbury JB et al. The Metabolic Basis of Inherited Disease, New York: McGraw-Hill, New York, USA, p. 204-228. 